\title{
The Troubles in Northern Ireland and Theories of Social Movements
}

\author{
Edited by \\ Lorenzo Bosi and Gianluca De Fazio
}


Cover illustration: Two rows of RUC Land Rovers keeping warring factions, the Nationalists (near the camera) and Loyalists, apart on Irish Street, Downpatrick. bho1064

Bobbie Hanvey Photographic Archives (MS2001.039), John J. Burns Library, Boston College

Cover design: Coördesign, Leiden

Typesetting: Crius Group, Hulshout

$\Lambda$ msterdam University Press English-language titles are distributed in the US and Canada by the University of Chicago Press.

$\begin{array}{ll}\text { ISBN } & 9789089649591 \\ \text { e-ISBN } & 9789048528639 \text { (pdf) } \\ \text { DOI } & 10.5117 / 9789089649591 \\ \text { NUR } & 686\end{array}$

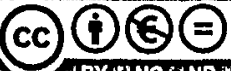

Creative Commons License CC BY NC ND (http://creativecommons.org/licenses/by-nc-nd/3.0)

$\circledast \Lambda \mathrm{ll}$ authors / $\Lambda$ msterdam University Press B.V., $\Lambda$ msterdam, 2017

Some rights reserved. Without limiting the rights under copyright reserved above, any part of this book may be reproduced, stored in or introduced into a retricval system, or transmitted, in any form or by any means (electronic, mechanical, photocopying, recording or otherwise). 


\title{
7 Social Movements and Social Movement Organizations
}

\author{
Recruitment, Ideology, and Splits' \\ Robert W. White and Tijen Demirel-Pegg
}

\section{Social Movements and Social Movement Organizations}

A common interpretation of the Irish 'Troubles' is that they began in the late 1960 s when counterdemonstrators supported by the Royal Ulster Constabulary (RUC) attacked peaceful civil rights protesters. 'Out of the Ashes' of August 1969 arose the Provisional Irish Republican Army (IRA) and 'Provisional' Sinn Féin. It is also widely assumed that the conflict ended in 1998 when the Provisionals accepted the Good Friday Agreement and settled for a reformed Northern Ireland (see also Bosi and De Fazio, in this volume).

The transformation of the Provisionals from revolutionaries to constitutional politicians is only part of the story, however. The Provisional IRA and Sinn Féin were not the Irish republican movement. They were two of several 'players' in the Irish republican 'arena' between 1969 and 1998 (Jasper 2015; Mische 2015; Bosi and Della Porta 2012). Other organizations included Cuman na mBan and the Irish National Liberation Army. Placing the Provisionals in the context of the Irish republican movement allows an examination of their origins and how they changed over time, and shows how they were part of a series of waves of Irish republicanism.

Tarrow (1989) argues that mobilization occurs in waves and focuses on processes of escalation and de-escalation in recruitment. Placing an organization in the context of the social movement as a whole provides insight on organizational dynamics during waves of recruitment and during the 'lean' years between waves.

The timing of recruitment, the geographic location of new members, and their political background/upbringing, influence the new recruit's understanding of what s/he joined (ideology). When founding members

1 Revised paper presented at the first anmal Ruairí Ó Brádaigh Summer School, Roscommon, Ireland, June 2014. Thanks to Lorenzo Bosi, (ianluca l)e lazio, Dieter Reinisch, Margaret White, and Terry l: White for their help and comments. 
Figure 7.1 Heuristic Model

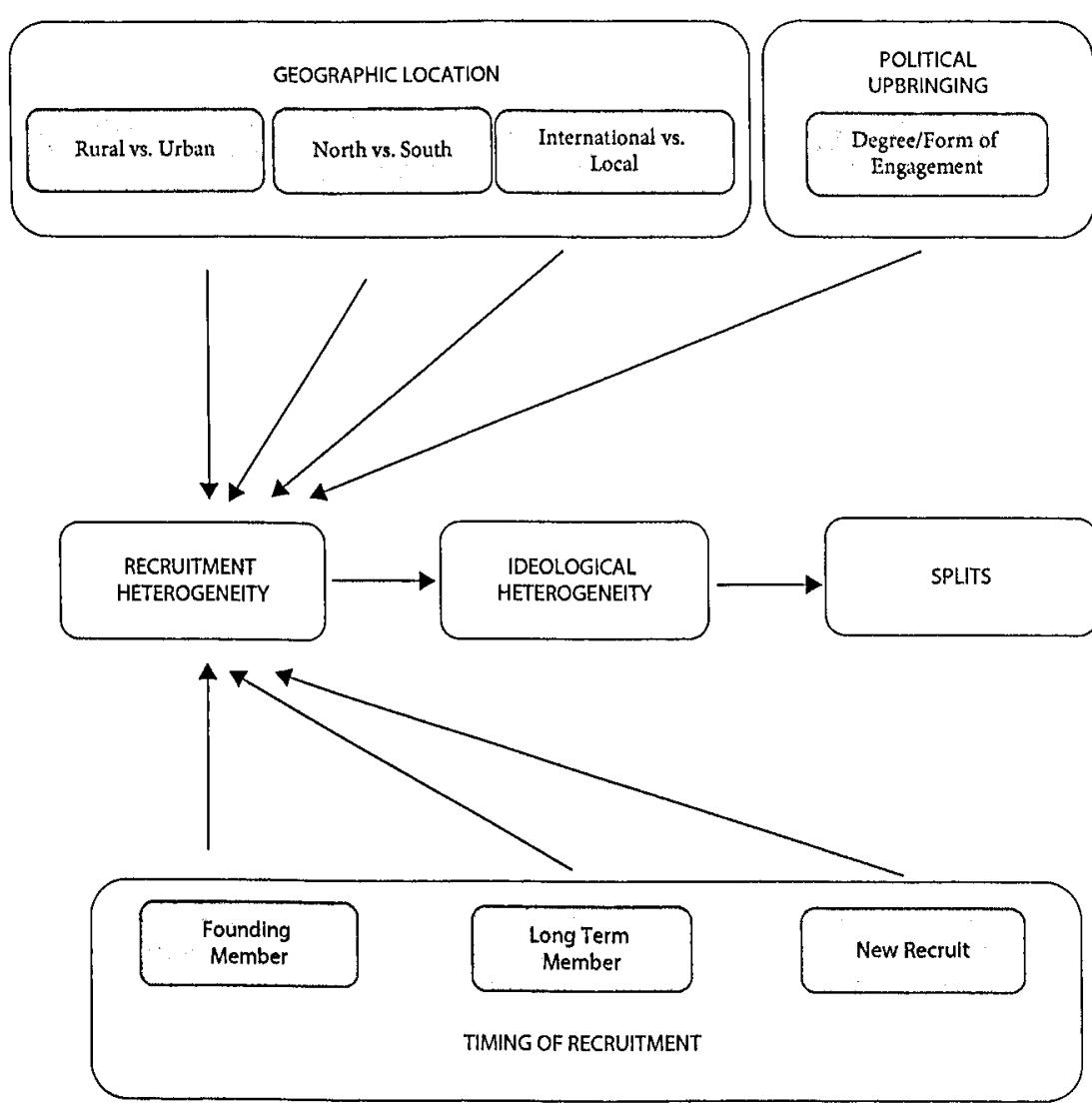

recruit new members, the new recruits enter an organization whose members have already established an understanding of who they are and what they are about. Even if new recruits join because of a commitment to the organization's ideology, a certain level of heterogeneity is inevitably introduced (see also White 1993, 2017; Weinstein 2007). The politics of where the new members live, their upbringing and family politics, and the timing of recruitment also influence the level of cohesion and homogeneity among members. Membership heterogeneity influences the likelihood of splits. For example, heavy state repression may create conditions for mass mobilization, but it may also bring in members who are more likely to be co-opted. An end to repression may satisfy new recruits but not founding members whose significant sacrifices in pursuit of a full victory pre-date the arrival of the new recruits. In summary, geographic location, family political background/upbringing, and the timing of recruitment contribute to the heterogeneity of movements, leading to factions and splits (Garner and Zald 1987; Freeman 1978; Gamson 1990; Demirel-Pegg forthcoming).

Figure 7.1 is a heuristic. We acknowledge, for example, that the timing of recruitment may directly influence ideology and that external factors influence splits (e.g. Balser 1997). The figure does not convey the full dynamics of activism. Instead, it is an attempt to convey important mechanisms associated with activism, as found in the following case study of Provisional Irish republicans within the context of the Irish republican movement.

\section{In the Beginning: The Wave of the Early $1970 \mathrm{~s}$}

In August 1969, the RUC was unable to maintain order in Derry and violence spread to other areas of Northern Ireland. In Belfast, nationalist/Catholic neighbourhoods were attacked by Protestant/loyalist vigilantes and the RUC. A Belfast respondent described what happened in his neighbourhood":

Clonard republican: I lived in an area that was called the Clonard. The Clonard area in ' 69 , Bombay Street is in the area, right? The Clonard is completely - it's smaller, it has thirteen streets, right? At the bottom of the street it - [it is a] fringe off the Shankill Road area. In ' 69 the area was attacked from the Shankill Road along Lawnbrooke Avenue by $B$ Men, which were sort of paramilitary reservish policemen. The loyalists attacked the area. At that time there was only a couple of hunting guns in the area. Like shotguns. Nobody was able to defend the area, right? So, I decided, myself decided, the best way to defend the area is to get involved in the republican movement.

The respondent joined Na Fianna Éireann, the youth wing of the Irish republican movement.

Unrest from both communities escalated and on 9 August 1971 the British gave the Northern Irish government permission to introduce internment without trial. Even though nationalists and unionists had engaged in violence, only nationalist areas were targeted. Hundreds of nationalists were

2 Data collection began in 1984 and has continued through 2016 . Respondents include a variety of activists - women and men, senior and junior level, from across Ireland, cte. The initial wave of interviews $(1984 / 85)$ may be the most representative data cver collected from activists associated with a social movement engaged in an armed canpaign (White 1993). Somer quotations have been jresented elsewhere. 
interned without charge or trial (McGuffin 1973). This respondent joined the Provisionals after the introduction of internment:

Belfast republican: I'd seen many people shot dead. I'd seen friends' fathers who had been taken away and interned. I had friends whose relatives and maybe brothers and things like that were taken to Holywood, the interrogation centre at the time, and tortured. And all that from 1969 right up to just after internment, that was a real awakening for me on the injustices of the state.

On Sunday, 30 January 1972, at an anti-internment march, British soldiers shot dead thirteen unarmed nationalist/Catholics; a fourteenth died later. 'Bloody Sunday' influenced this respondent, from Derry:

Derry republican: It wasn't an emotional response, that 'I hate the Brits it's about time I did something', you know? It was just that I'd always been concerned, I'd always been motivated towards things Irish and it was just another - it was just another act of political vandalism on Irish people. [...] The British were killing our people, they were locking them up and they were nothing more than Stormont [the Northern Ireland government].

These respondents were influenced by violence, defending a neighbourhood from loyalists and suffering repression at the hands of the RUC and the British Army (see also De Fazio 2013; Demirel-Pegg 2014).

Not every Northern Irish recruit immediately joined the Provisionals in response to state or loyalist violence. Factors like the belief that political violence would be effective and camaraderie with peers influenced their decision-making processes (Bosi and Della Porta 2012; Klandermans 1984; McAdam 1999; White 1989). The repression also interacted with family background. Persons from republican backgrounds were more easily and more quickly recruited. The respondent from Clonard was from a republican family and joined relatively quickly in response to August 1969 . The respondent from Derry, who was not from a republican family, joined the Provisionals more than a year after Bloody Sunday (see also Bosi 2012). Also, the violence did bring in recruits who were not from Northern Ireland but were mobilized because state violence was an affront to their sense of national identity.

What is important is that the state violence created a fertile ground for the founders of the Provisionals as they sought recruits from all over Ireland. As the state's response de-legitimated the state's authority, young Northern Irish nationalists came to believe that they were second-class citizens in a state that could not be reformed. Their best political choice, it seemed, was to support armed struggle for a united Ireland via the Provisional IRA and Sinn Féin. Family upbringing may have facilitated recruitment, but state repression turned the Provisionals into a mass movement in Northern Ireland (Bell 1979; White 2017).

Understanding this mass mobilization and the heterogeneity it introduced is essential for understanding why the Provisionals were willing to settle for the Good Friday Agreement. As the conflict continued, young northerners - many of whom were recruited in the early 1970 s - came to dominate the Provisionals. Belfast ended up with more Provisionals than any other area of Ireland. Key younger people moved into leadership positions, including Gerry Adams in Belfast and Martin McGuinness in Derry. Finally, because those in the war zone suffered disproportionately, the Northern voice became especially important.

At some point in the early 1990 s, the new Provo leadership realized that armed struggle was not going to lead to a united Ireland. A negotiated peace that fell short of a united Ireland but led to a reformed Northern Ireland where they would have a political voice became an at tractive option for people who had been deeply influenced by state violence in the early 1970s. The Good Friday Agreement, which promised that Irish nationalists would no longer be treated as second-class citizens in Northern Ireland, was a significant achievement. The people who settled for reform were not necessarily the people who created the Provos, however.

\section{Before the Provisionals}

Modern Irish republicanism dates from the failed Easter Rising of 1916 . Between 1919 and 1921, the IRA and Sinn Féin re-grouped and pursued a guerrilla war and a political campaign for an independent Irish republic. In response, the British passed the Government of Ireland $\Lambda \mathrm{ct}(1920)$ and partitioned Ireland into the six counties of Northern Ireland, where the majority Protestant population wanted to remain a part of the United Kingdom, and the Irish Free State (declared the Republic of Ireland in 1949), where the vast majority of the people were Catholic and wanted an independent Irish Republic. The IRA and Sinn Féin split over the Anglo-Irish Treaty (1921), which confirmed separate parliaments in Dublin and Belfast. Irish republicans who rejected the treaty lost the Irish Civil War that followed but maintained the IRA and Sinn Féin and continued their pursuit of an all-Ireland republic. There were failed IR A campaigns in the 1940 and 1950 s in pursuit of an independent and united Ireland (Bell 1979). 
When the violence flared in Northern Ireland in August 1969, Irish republicans disagreed on the most appropriate response. The then leadership of the IRA and Sinn Féin, veterans from the 1940s and 1950s, argued that the IRA and Sinn Féin should recognize the Dublin, Belfast, and London parliaments and combine armed struggle with constitutional politics. The people who created the Provisional IRA and Sinn Féin were also veterans from the 1940 and 1950 s. This group of people believed that recognizing those parliaments violated fundamental principles and would be a strategic mistake. Their view was that participation in constitutional politics would inevitably lead to co-optation and settling for reforms that were short of a united Ireland. The disagreement led to a split of the IRA in December 1969 into the 'Official' IRA and the 'Provisional' IRA. In January 1970, Sinn Féin split into 'Official' Sinn Féin and 'Provisional' Sinn Féin.

Most important, the people who created the Provisionals were different from the young recruits of $1969-1972$. The people who created the Provisionals were involved in the movement prior to August 1969. In Tyrone's Struggle, Gerard Magee quotes a pre-1969 IRA volunteer who said, 'I didn't need to be struck over the head by an RUC baton to become an active republican' (Magee 2011: 124). To paraphrase a critic of Martin McGuinness, 'He got his start throwing rocks at the RUC'. The Irish republican movement spans Ireland. In August 1969, and because of where they lived, some Irish republicans were not in a position to be hit by officers of the Royal Ulster Constabulary.

Joe Cahill (1920-2004) helped create the Provisionals. He was born in Belfast in 1920. In contrast to many of the young northerners of 1969-1972, he was born into the Irish republican tradition:

Interviewer: [...] why in general did you get involved in the movement?

Joe Cahill: Yeah. I suppose it was the environment that I grew up in the '3os - poverty, and unemployment, and that sort of thing, you know? I felt that something had to be done about it. I became involved with various groups as a young lad. But I soon came to the conclusion that the root of all the trouble in Ireland was British occupation. And I suppose education through reading about Tone, people like that. The only way forward was to break the connection with England [...].

Interviewer: You're from a republican background?

Joe Cahill: I would be, yeah. Both my father and mother had been involved one way or another in the Republican Movement.
Cahill grew up in an environment where state repression was a part of life and armed struggle for a united lreland was an accepted response. He joined the IRA in the 1930 and was jailed during the IRA campaigns of the 1940 s and 1950s. He resigned from the IRA in the mid-196os because they were not militant enough. In August 1969, he returned and with others in Belfast helped create the Provisionals.

Most of the people who created the Provisionals did not live in Belfast or even Northern Ireland, however. Of the seven people on the Provisional IRA's first Army Council, five of them lived in 'southern Ireland' (the exceptions were Joe Cahill and Leo Martin, from Belfast). ${ }^{3}$ Of the 20 people on the 'Provisional' Sinn Féin Caretaker Executive established in 1970, only two were from Northern Ireland.

Ruairí Ó Brádaigh (1932-2013), from Longford in the Irish midlands, was Chairman of the Caretaker Executive. He was the son of an IRA veteran wounded in 1919:

Ruairí Ó Brádaigh: He and another man, another volunteer, Willie McNally, attempted to disarm two members of the Royal Irish Constabulary, the predecessors of the RUC and the PSNI, and they were overcome by the two policemen. And both of them were wounded, my father very severely wounded, and he was disabled for life.

Ó Brádaigh's mother was a veteran of Cumann na mBan, an independent women's organization founded in 1914:

Ruairí $O$ Brádaigh: She was $\mathrm{O} / \mathrm{C}$ or captain of the Cumann na mBan branch in Donegal Town in 1917 and ' 18 and then when she went to Dublin as a student at University College Dublin. She was a member of the college branch of Cumann na mBan and took part in all its activities.

Like Joe Cahill, Ó Brádaigh grew up in a household that valued Irish culture:

Ruairí Ó Brádaigh: Tuesday and Friday evening, paying a penny each, we were sent to Irish classes in the town, from five o'clock to seven. The first hour being Irish language and history and second hour being ceili dancing, Irish dancing, and with an annual fancy dress ceili and all that - cultural activities.

3 'Southern Ireland' refers to the Irish Free State/Republic of Ireland, parts of which are worth of Northern Ireland. We argue that Irish Republicans born and raised in Northem Ireland are politically and socially different from persons bon and raised elsewhere. 
Ó Brádaigh joined Sinn Féin in 1950 and the IRA in 1951. He was Chief of Staff at the end of the 1956-1962 IRA campaign. He was on the Provisional IRA's first Army Council and became the first President of 'Provisional' Sinn Féin (henceforth, Sinn Féin). The founders of the Provisionals, Joe Cahill, Ruairí $O$ Brádaigh, and their contemporaries, were middle-aged men and veteran activists.

When the Provisionals were created, there were also other organizations, including the 'Official' IRA and 'Official Sinn Féin'. Cumann na mBan opposed the 1921 treaty and after the Irish Civil War held political values parallel to those of the IRA and Sinn Féin. Peig King joined in Dublin in the 1940s. Like Cahill and Ó Brádaigh, she was from a republican family. When she joined, her older sister was already a member:

Interviewer: Why did you get involved in Cumann na mBan?

Peig King: In Cumann na mBan? I knew about Cumann na mBan, my mother was in it. And all along the line, my father and mother was involved...

\section{Interviewer: When did she get involved?}

Peig King: She was involved when - she was in Dublin in 1916. [...] She was involved all along, right. My father was involved as a young man. [...]

\section{Interviewer: Was he an IRA Veteran?}

Peig King: Yes, he was. Yes. Yeah.

In $1969 / 7^{0}$, the Cumann na mBan leadership agreed with the political analysis of those who founded the Provisionals (Reinisch 2016). Peig King, while still a member of Cumann na mBan, joined Sinn Féin in 1970.

\section{Recruitment, Ideology, and Resistance to Change - And a Second Wave of Recruits}

Joe Cahill, Ruairí Ó Brádaigh, Peig King, and their contemporaries, joined small, clandestine organizations, not mass movements. They shared political backgrounds and accepted the view that the Dublin and Belfast governments established by the Government of Ireland Act (1920) were illegitimate. Their allegiance was to an all-Ireland government that was suppressed in the 1920 s and abandoned by former comrades of their parents.

Depending upon where they were born and raised, however, the people who created the Provisionals grew up in very different worlds. Joe Cahill grew up in Northern Ireland, which was predominantly Protestant and proUnion, and where Catholics/nationalists were second-class citizens. Ruairi Ó Brádaigh grew up in the Irish Free State/Republic of Ireland, which was predominantly Catholic and Irish nationalist in outlook. Because of their politics, both of them suffered repression at the hands of their respective governments. Cahill and his fellow northerners were also victims of social oppression because of their religion and their sense of national identity. For many northerners, the Dublin government was not legitimate, but it was also distant and appeared relatively benign.

As the Provisionals carried on their campaign to re-unite Ireland, some of their founders, including Joe Cahill and Ruairí Ó Brádaigh, were arrested. Others aged and left the scene. With time, younger people - especially people born and raised in Northern Ireland - moved into leadership positions. With them came change. For example, at the initiative of young northerners, the Provisional IRA adopted a cell structure (small active service units) in the late 1970s.

The new leaders also tried to disband Cumann na mBan and fold its members into the Provisionals. From their perspective, the Provisionals were progressive and there was no need for a separate women's organization. From the Cumann na mBan perspective, there was a concern that the new leadership was trying to find a way to better control women activists. Cumann na mBan refused to go along with the plan (though some women did leave for the Provos):

Interviewer: Why is it important that there's a separate women's organization?

Cumann na Mban activist: I think it's important from the point of view that women tend to become subsumed - well at that particular time [1970s] women's role was more I think subservient than it would be now, you know? Women were only just kind of standing up and being counted. And I think it was always important for the Republican Movement that women had a separate voice and could stand up for themselves. Because even now I think that women in the male military organization are very much at the mercy of their male counterparts. And I would rather, as a woman, have my own voice and be able to make it known. 
The key point here is that the beliefs and ideology of members of a preexisting organization were so strong that they refused to be absorbed into a larger movement organization with the same goal. This did not stop the younger people from changing the Provisionals in other ways.

A second wave of new recruits, generated by the 1980-1981 hunger strikes, solidified the control of the younger and northern leadership (White 2017; see also O'Hearn, this volume). Led by Gerry Adams, Martin McGuinness, and Danny Morrison, the new leaders changed Sinn Féin's policy so that elected representatives could take seats in the Dublin parliament. They also promised that they would never take seats in a Northern Ireland parliament. That promise made it easier for senior northerners, like Joe Cahill, to accept the change.

The opposition to taking seats in the Dublin parliament was led by people recruited long before there were Provisional Irish republicans, senior 'southerners' (or, non-northerners) like Ruairí Ó Brádaigh. They, and their families, had personally experienced repression at the hands of the Irish Free State/ Republic of Ireland; the illegitimacy of the Dublin government was immediate for them. They walked out of the 1986 Sinn Féin Ard-Fheis (convention) and created two rival social movement organizations, Republican Sinn Féin (RSF) and the Continuity IRA. Cumann na mBan also opposed taking seats in the Dublin parliament.

The 1986 split has several implications for studying social movements and their organizations. What happens in one movement organization, like Sinn Féin, influences other movement organizations, like Republican Sinn Féin and Cumann na mBan. From 1986 on, RSF and Cumann na mBan (two small organizations) adopted a mutually supportive approach and several members of Cumann na mBan would become officers in RSF; today, Peig King is the 'Patron' of Republican Sinn Féin. Cumann na mBan did not join RSF en masse or through bloc recruitment, but their influence on RSF is undeniable (Ní Chathmmhaoil and Reinisch 2014).

The split also shows that when and where someone is recruited influences that person's understanding of what s/he has joined and the course of his/her activism, which has been noted previously (see also White 1993; White 2010; Weinstein 2007; Viterna 2013). As Sarah Campbell (in this volume) nicely demonstrates, collective identities promote solidarity among members of a social movement. At the same time, differences in collective identities across subgroups of activists in the same organization may promote factions and splits. This was demonstrated a second time in 1997.

Eleven years after the first split, the senior northerners still active in the Provisionals, including Joe Cahill, went along with the (still relatively) young leadership as they negotiated the Irish peace process. The primary opposition was a group of activists who were willing to accept Sinn Féin taking seats in the Dublin parliament but who questioned the Provisional IR A's ceasefire in 1997 and, later, the Good Friday Agreement. They challenged the leadership and created the 32 County Sovereignty Committee, which they described as a pressure group within Sinn Féin. Of the 16 people on the committee's 'Executive', only four were from Northern Ireland. They were committed to a united Ireland, not a reformed Northern Ireland where many of them did not live. After being expelled from Sinn Féin, they re-organized as the $3^{2}$ County Sovereignty Movement. It is alleged that the 32 CSM is the 'political wing' of the Real IRA (Mooney and O'Toole 2003).

The Irish Republican Movement: 1998 to Today

The Irish republican movement did not end with the Good Friday Agreement in 1998. Post-1998, Sinn Féin politics dominated the Provisionals to the extent that the Provisional IRA formally ended its campaign and decommissioned weapons in 2005 . And the peace process has been good to Sinn Féin. In Northern Ireland, they are the second largest party and Martin McGuinness served as the Deputy First Minister of the Northern Ireland Assembly until 2017 - in spite of having promised to never serve in such an assembly. In the Republic of Ireland, Sinn Féin is the third largest political party and Gerry Adams is leader of their parliamentary party in Dáil Éireann (the Dublin parliament). North and south, Sinn Féin's representatives still advocate for a united Ireland.

Republican Sinn Féin, the Continuity IRA, the 32 County Sovereignty Movement, the Real IRA, and Cumann na mBan, all rejected the Good Friday Agreement and continued as social movement organizations. $\Lambda \mathrm{fter}$ 2005 more organizations appeared, including Éirigi, the Republican Network for Unity (RNU), and the Óglaigh na hÉireann (ONH). $\Lambda$ focus on the Irish republican movement brings the activities of these groups into view, and also provides more insight on the transformation of the Provisionals.

Indeed, this case study offers insight on what happens between waves of mobilization and de-mobilization. The process of recruitment to organizations that reject the Good Friday Agreement appears to be similar to the recruitment process of those who joined after the mass mobilization of 1916-1923 but prior to the mass mobilization of the early 1970 . The following is from an activist who joined Republican Simn Féin in 2000:

Republican Sinn Féin activist 1: I would like to say I just woke up one morning and decided I wanted to see the freedom of my country, but I was 
brought up in a very republican household, in the republican tradition [...] I've been reared in the republican tradition and I've always known that, you know, we're under occupation and that the freedom of your country is a noble aspiration, it's not something you should be ashamed of.

Like Joe Cahill, Ruairí Ó Brádaigh, and Peig King, this activist was strongly influenced by family background. When armed struggle by Irish republican activists is limited - in the 1930s (Cahill), the 1940s (King), the early 1950s (Ó Brádaigh), and the 200os - family connections are that much more valuable a source of recruits (see Veugelers 2011; Della Porta 1988).

Family connections and repression have never been the only source of recruits to the Irish republican movement. Another person who joined Republican Sinn Féin in the early 200os commented:

Republican Sinn Féin activist 2: I suppose just all my life I've felt that continued British rule in Ireland was unjust and immoral as well as illegal and so I suppose in a sense it was merely inevitable [that I would become involved].

The Good Friday Agreement did not resolve the fundamental issue that has sustained Irish republicanism since the 179os. Ideology, the belief that Ireland should be free, continues to motivate recruits to organizations that engage in armed struggle.

However, family connections and the belief that Ireland should be free do not provide recruits to the degree that events like August 1969, internment, and Bloody Sunday sent recruits into the Provisionals in droves. Compare 'I was brought up in a very republican household' and 'British rule in Ireland was unjust and immoral as well as illegal' with 'The best way to defend the area is to get involved in the republican movement'. If, in the early 2000 , there had been a re-occurrence of widespread state repression, there might also have been a groundswell of support for organizations like the Continuity IRA and the Real IRA. That did not happen.

In the wave of mobilization that generated the Provisionals, the British learned that widespread repression was counterproductive in Northern Ireland. Therefore, they turned to selective repression, a more sophisticated approach. In response to continued political violence from so-called 'dissident' organizations, the British, Irish, and Northern Irish (which includes Sinn Féin) governments have replaced the counterproductive repression of the early 1970 s with a more sophisticated approach - 'internment by remand'. Dissent is selectively repressed. Martin Corey was arrested in
April 2010. A 'Release Martin Corey' campaign was organized, but because he was one person its appeal was less successful than the anti-internment campaign of 1971-1972; the anti-internment march on Bloody Sunday attracted thousands. Corey's attorneys were not allowed to view the evidence against him, he was never allowed a parole hearing, and when he was finally released in January 2014 - without ever being charged - it was with restrictions. Activists in the Irish republican movement still face repression, even if the Provisionals do not.

There is also a curious situation with respect to Cumann na mBan. Sinn Féin claims that it is progressive on women's issues. Policies were adopted to enhance the role of women in Sinn Féin and the party proudly promotes women candidates and its elected women representatives. Michelle O'Neill, for example, is the party's new leader in Northern Ireland. The party also embraces Cumann na mBan's historic contribution to Irish republicanism, including having women dressed in 1916-1922 era Cumann na mBan uniforms appear at their events. And yet, while promoting women's activism, and because Cumann na mBan did not follow the Provisionals into constitutional politics, Sinn Féin claims that the organization ceased to exist in the late 1980 s.

Cumann na mBan still exists, still sees the Dublin and Belfast parliaments as reformist institutions established by the British to maintain their rule in Ireland, and still considers itself a revolutionary organization:

Interviewer: I've heard it said that the more progressive women got involved in the movement more generally, and weren't interested necessarily in a women's organization because they felt they were equal, etc.

Cumann na Mban activist: Is that like in the Provisionals?

Interviewer: Yes.

Cumann na Mban activist: Yes, indeed, they were the ones that followed their men very, very, quietly into constitutional politics. And that's the answer to that. I mean, they weren't revolutionary. I know most of those women. And I was with them in Sinn Féin. Some of them would have been in Cumann na mBan at times. But if you look at Sinn Féin [...] you had this idea of having eight places reserved on the Ard Chombairle for women. I never agreed with that. I think people should be recognized on their merits. And in Republican Sinn Féin [...] We don't have tokenism, you know? [...] Revolutionary women would stand by the Republic and 
stand by what they believe in and they won't worry about their husbands or their boyfriends, or their brothers or sisters - brothers, you know, and they stick up to their beliefs.

Interviewer: Are you a revolutionary?

Cumann na Mban activist: I would think so. I've always been a revolutionary.

For some observers, the women who stayed with Cumann na mBan, were less progressive and less feminist than their counterparts who went into the Provisionals (O'Keefe 2013: 135; see also O'Keefe, in this volume). This Cumann na mBan activist argues that the women who went with the Provisionals lost their revolutionary way.

\section{Summary}

Placing the Provisional IRA and Sinn Féin within the 'arena' of the broader Irish republican movement and following these two organizations over time offers insight on their transformation and the rise of anti-Good Friday Agreement 'dissidents' who pursue armed struggle today. Preexisting organizations, the timing of recruitment, and different belief systems among groups of activists influenced the Provisionals. So did events post-1969.

More generally with respect to activism, the Irish republican movement has experienced waves or cycles of mass mobilization, as occurred in 1919-1921 following the Easter Rising, in the early 1970s in response to state violence, and in 1980-1981 in response to the hunger strikes. Yet, the dynamics of activism during the lean years cannot be ignored. Even if the number of recruits is smaller between waves of recruitment, differences in the nature of recruitment during these years versus recruits brought in during a mass mobilization are important, as they may lay a foundation for splits.

Many social movements have lengthy histories with multiple social movement organizations. Without question, in-depth case studies of recruitment into specific organizations, including studies that focus on a particular period of time, have value. However, this case study of Provisional Irish republicans, over time and in the context of the broader Irish republican movement, shows that we cannot assume that activists within the same movement (or even the same social movement organization) experience the same recruitment process. These differences contribute to movement heterogeneity and organizational change. Finally, the persistence of some organizations in the face of external opposition from states and internal opposition from other movement organizations, like Cumann na mBan, merits further consideration.

\section{Interviews}

Belfast Republican, 1996

Clonard Republican, 1984

Cumann na mBan activist, 2009

Derry Republican, 1985

Joe Cahill, 1996

Peig King, 2009

Republican Sinn Féin activist 1, 2011

Republican Sinn Féin activist 2, 2011

Ruairí Ó Brádaigh, 2009

\section{Works Cited}

Balser, Deborah B. 1997. "The Impact of Environmental Factors on Factionalism and Schism in Social Movement Organizations'. Social Forces 76.1: 199-228.

Bell, John Bowyer. 1979. The Secret Army: The IRA 1916-1979. Dublin: Academy Press. Bosi, Lorenzo. 2012. 'Explaining Pathways to Armed Activism in the Provisional Irish Republican Army, 1969-1972'. Social Science History 36.3:347-90.

Bosi, Lorenzo, and Donatella della Porta. 2012. 'Micro-mobilization into Armed Groups: The Ideological, Instrumental and Solidaristic Paths'. Qualitative Sociology $35 \cdot 4: 3^{61-383}$.

Bosi, Lorenzo, and Simon Prince. 2009. 'Writing the Sixties into Northern Ireland and Northern Ireland into the Sixties'. The Sixties: A Journal of History, Politics, and Culture 2.2: 145-161.

De Fazio, Gianluca. 2013. "The Radicalization of Contention in Northern Ireland, 1968-1972: A Relational Perspective. Mobilization 18.4: 475-96.

Della Porta, Donatella. 1988. 'Recruitment Processes in Clandestine Political Organizations: Italian Left-Wing 'Terrorism'. In International Social Movement Research, ed. B. Klandermans, H.P. Kriesi, and S. Tarrow. Greenwich, CT: JAI Press, $155-169$. 
Demirel-Pegg, Tijen. 2014. 'From the Streets to the Mountains: The Dynamics of Transition from a Protest Wave to an Insurgency in Kashmir'. Mobilization 19.3: 309-327.

Demirel-Pegg, Tijen. Forthcoming. 'The Dynamics of the Demobilization of the Protest Campaign in Assam'. International Interactions. DOI: $10.1080 / 03050629.2016 .1128430$.

Freeman, Jo. 1978. 'Crises and Conflicts in Social Movement Organizations' Chrysalis: A Magazine of Women's Culture 5: 43-51.

Gamson, William. 199o. The Strategy of Social Protest. Belmont, CA: Wadsworth. Garner, Roberta Ash, and Mayer N. Zald. 1987. 'The Political Economy of Social Movement Sectors'. In Social Movements in an Organizational Society: Collected Essays, ed. Mayer N. Zald and John McCarthy. New Brunswick, NJ: Transaction, 293-317.

Jasper, James M. 2015. 'Introduction: Playing the Game'. In Players and Arenas: The Interactive Dynamics of Protest, ed. James M. Jasper and Jan Willem Duyvendak. Amsterdam: Amsterdam University Press, 9-32.

Klandermans, Bert. 1984. 'Mobilization and Participation: Social-Psychological Expansions of Resource Mobilization Theory'. American Sociological Review 49: 583-600.

Magee, Gerard. 2011. Tyrone's Struggle: Ar son Saoirse na hEireann. Dublin: Brunswick Press.

McAdam, Doug. 1999. Political Process and the Development of Black Insurgency, 1930-1970. Chicago: University of Chicago Press.

McGuffin, John. 1973. Internment! Dingle: Anvil Books.

Mische, Ann. 2015. 'Fractal Arenas'. In Players and Arenas: The Interactive Dynamics of Protest, ed. James M. Jasper and Jan Willem Duyvendak. Amsterdam: Amsterdam University Press, 55-78.

Mooney, John, and Michael O'Toole. 2003. Black Operations: The Secret War against the Real IRA. Ashbourne: Maverick House.

Ní Chathmmhaoil, Líta, and Dieter Reinisch. 2014. Cumann na mBan: 100 Years Defending the Republic. Dublin: Cló Saoirse - Irish Freedom Press.

O'Keefe, Theresa. 2013. Feminist Identity Development and Activisms in Revolutionary Movements. London: Palgrave Macmillan.

Reinisch, Dieter. 2016. 'Cumann na mBan \& Women in Irish Republican Paramilitary Organisations, 1969-1986'. Estudios Irlandeses 11: 149-162.

Tarrow, Sidney. 1989. Democracy and Disorder: Protest and Politics in Italy, 1965-1975. Oxford: Oxford University Press.

Veugelers, John W.P. 2011. 'Dissenting Families and Social Movement Abeyance: The Transmission of Neo-Fascist Frames in Postwar Italy'. British Journal of Sociology 62.2: 241-261.
Viterna, Jocelyn. 2013. Women in War: The Micro-Processes of Mobilization in II Salvador. Oxford: Oxford University Press.

Weinstein, Jeremy M. 2007. Inside Rebellion: The Politics of Insurgent Violence. Cambridge: Cambridge University Press.

White, Robert W. 1989. 'From Peaceful Protest to Guerrilla War: Micro-mobilization of the Provisional Irish Republican Army'. American Journal of Sociology 94.6: 1277-1302.

White, Robert W. 1993. Provisional Irish Republicans: An Oral and Interpretive History. Westport, CT: Greenwood Press.

White, Robert W. 2006. Ruairí Ó Brádaigh: The Life and Politics of an Irish Revolutionary. Indianapolis: Indiana University Press.

White, Robert W. 2010. 'Structural Identity Theory and the Post-Recruitment Activism of Irish Republicans: Persistence, Disengagement, Splits, and Dissidents in Social Movement Organizations'. Social Problems 57.3: 341-370.

White, Robert W. 2017. Out of the Ashes: An Oral History of the Irish Republican Movement (SocialMovements versus Terrorism). Newbridge, C. Kildare, Ireland: Merrion Press. 